\title{
Conflict Resolution after the Memorandum of Understanding (MoU): Case Study of Langsa, Aceh Province, Indonesia
}

\author{
Dr. Bambang Wahyudi, M.M., M.Si \\ Peace And Conflict Resolution Study Program \\ Indonesia Defense University (IDU) \\ Indonesia Peace and Security Center (IPSC) Bogor \\ Indonesia
}

\begin{abstract}
Conflict resolution is not just about ending violence, but how to build peace afterwards. Taking a case study in Langsa, this study presents an overview of how the conflict in Aceh has been transformed. It then proposes a framework that allows conflict parties to reconcile or even transform injustices to build peace in a non-violent way. In Aceh case, the peace agreement between the Government of Indonesia (RI) and Aceh Free Movement $(G A M)$ is limited to the termination of armed conflict. Moreover, there has been a shift from the vertical between "Aceh" and "Jakarta" becoming horizontal, between Acehnese people (Aceh GAM and Aceh RI). This shift indicates that the Helsinki MOU still leaves social integration issues that will be potential to fuel the next conflict. The comprehensive conflict resolution still takes time due to constraints such as ethnic sentiment and differences expectations of Acehnese towards peace.
\end{abstract}

Keywords: Conflict Resolution, Conflict Reconciliation, Conflict Transformation, Peace, Development.

\section{Introduction}

Globalization makes issues related to human rights to be prominent. Political, economic and social changes are often followed by the emergence of various conflicts. One of them is the interstate conflict that affects many unties, the emergence of nationalism spirit that trigger the separatist movement. There is an insistence on selfdetermination based on social and cultural issues, political and regional interests, and primordial equations in race, ethnicity and religion (Micheal 1993: 5). The meaning of the conflict is quite prevalent in Indonesia during the reformation era (Baskoro, 2002: 6), such as the incidents in Papua, Maluku, Aceh, and East Timor demanding independence. As one of conflict with separatism background, conflict in Aceh is not easy to be figured out completely due to its complex problem. There are issues related to the past, welfare, political, and economic revenge that led to the demand to escape from the Unitary State of the Republic of Indonesia (NKRI). All these problems are interrelated and difficult to resolve partially. Although the Helsinki MOU has been regarded as a peaceful means of resolving the Aceh conflict, the MOU seems to be only an agreement between the Indonesian government and GAM, which does not involve elements of other Acehnese societies (Julan, 2005: 196). Meanwhile, vehemence and combats in Aceh since 1976 has involved three parties; the central government, GAM, and the non-GAM Aceh community (Gardono, 2005). This explains the urgency that social integration in Aceh basically still requires a follow-up process after the MOU and only relying on the MOU obviously is inadequate because positive peace 1 is still in a very early stage of development.

In the case of the Aceh conflict, the phenomenon of the emergence of pro and contra group divisions against the power of the Central Government tends to be incomplete after the ceasefire agreement and potentially leads to sustained conflict. The community dichotomy in the conflict area always follows

1 Positive peace is related to the application of social justice through equal opportunity, the distribution of power and resources, equal protection, and impartial law enforcement. The concept of positive peace also addresses the roots of war, violence, and conscious effort to build a society that reflects its commitments (Galtung, 1998: 10). the grouping of the conflicting parties. In addition to Aceh with the emergence of pro-NKRI (Acehnese) and proGAM (Aceh GAM) groups, the emergence of such a dichotomy has also occurred in Timor-Leste. 
This former 27th Indonesian province has experienced division of society into pro-independence (Fretelin/Falintil) and pro integration of Indonesia. Since reformation in Indonesia, pro-integration groups have often been subjected to various acts of violence, terror, intimacy, kidnappings, by pro-independence parties. (Ijie, 2003, 100).

This then becomes an urgency of research in addition to the need for a deeper knowledge of the identity of Acehnese Non-GAM people. Furthermore, Langsa has become a city with Aceh GAM's power map and relatively balanced Aceh RI. The implications of the pattern lead to an assessment of the conflict solution through the Helsinki MOU that has not yet touched the essence of a positive peace. For this urgency, this study was conducted to try to answer why in Aceh conflict, especially in Langsa emerged Acehnese groups that were anti to GAM and Central Government. In addition, the study also captures how the people of Aceh, especially Langsa, live in peace and understand the peace and potential for future conflicts. Ultimately this research tries to find out how the formulation of conflict resolution can be developed towards positive peace to prevent a new conflict in Aceh. All three are elaborated as a reflection of creating positive conflict in a wider scope.

\section{Theoretical Framework}

This study takes the topic of conflict perceived as a social process that can be analyzed in three dimensions, namely the causes of conflict, conflict dynamics, and conflict resolution. 2 In general, conflict theory only explains that conflicts can occur if in social relationships between groups / institutions inequality of exploitation and the existence of dominance exist. In human life, conflict is an inseparable part as in the form of real conflict that is not easily understood.3 According to the Hugh Miall conflict study in his Conflict Resolution of Contemporary Conflict (Tri BS translation, 2002), conflict is, in addition to an intrinsic aspect of social change, essentially also an expression of the heterogeneity of interests, values, and beliefs that emerge as new formations due to changes in social politics (Miall, 2002: 14). In addition, Miall also acknowledges the fluidity of the conflict process, meaning that conflict is vulnerable to changes that demand conflict resolution approach which also adjusts the dynamics of interests and preferences of complex 2Conflict Theory generally recognizes and analyzes the presence of conflict in social life, cause and form in many ways and its effects on social change (Lawong, 1986: 162). 3 Julan (2005: 10-11) states that conflicts in Indonesia can generally be categorized into two. Separatist conflicts or conflicts between the center and the regions are classified as vertical conflicts, whereas communal conflicts or other examples of ethnic and religious conflicts or natural resource conflicts are classified as horizontal conflicts. actors (Miall, 2002: 249). Concerning to conflict transformation without violence, Miall argues that there are five aspects that can be prior analyzed; t (1) context of transformation, (2) structure transformation, (3) actors of transformation, (4) issues of transformation, and (5) group and individual transformation (Miall, 2002: 250-252).

\section{Methodology}

Using qualitative approach, this research considers the process of research, events, and authenticity. As a form of implementation of the research problem, qualitative methods are used with the aim in phenomenon capturing of the emergence of pro-national and anti-separatist pro-government groups. Besides qualitative approach provides space for the subjectivity of researchers regarding the social dynamics in the field which is quite unmanageable if scrutinized mathematically. This study is a descriptive analysis designed to collect information about realness during the research period (Cresswel, 2003: 157). Data sources are collected from document, recording, archives, as well as opinions and understanding of figures through interviews. In addition to documentation and literature studies, data is also collected through unstructured interviews, observations4, and group observations are implemented to relevantphysical, social, and organizational objects captured using research instruments with audio, discussions 5. The determination of informants is purposive with 20 informants. Snow ball sampling plays a part to expand data source obtained from previous source. This research attempts to re-establish as a reflection of the important situation in the history of Indonesia's peace building over Aceh province in the integration of NKRI. The framing of time to be the focus of the analysis is after Helsinki MOU until the 2009 Election, where there are also tsunami events affecting social dynamics in Aceh as the conflict area.

\section{People and Conflict History of Aceh: Langsa}

Aceh is a province of Indonesia located on the northern tip of Sumatra Island with the official name of Nanggroe Aceh Darussalam (NAD). 
There are many nicknames attached to the area, such as Veranda of Mecca, Land of Rencong, or Lhee Sagoe Land. The term is a bit much to show the dynamics of Aceh's history closely related to the conflict7. It was previously visual, as well as audiovisual results. In this case the researcher is an observer, but deliberately does not involve themselves in activities that become the subject of observation. 6 Aceh Governor Regulation No. 46 Year 2009 dated April 7, 2009/11 Rabiul Akhir 1430 Hijriah concerning The Use of Aceh name and the title of government authorities in the official document structure of the Aceh Government.

The Aceh conflict began in the war against Portuguese domination in Indonesia as well as further Dutch colonialism. It did end up in that point. When Indonesia became an independent country, Aceh became the region an administrative area of North Sumatra, its status of privileges of NAD as a province until the year 2009 precisely encouraged the conflict because it had a psychological influence on the realization of a separate state, considering there has been a separatist effort since NKRI was established, so the name of NAD Province was changed into Aceh Province after the 2009 Election. Aceh province is mentioned by the author of The Population and Conflict Aceh, Aris Ananta (2007), as a multi ethnic Muslim province with at least eight ethnic residents, the described as having a high level of resistance. And therefore, the history of Aceh became full of conflict with the central government, such as in DI / TII rebellion, Cumbok War, and GAM emergence. Looking at its historical record, GAM was born out of a series of central government policy disappointments. First, during the presidency of Soekarno, there was a liquidation of Province of Aceh into the Province of North Sumatra that marked the loss of the status of a special region for Aceh. On 21 April 1953 a clerical congress in Medan was held discussing the transformation the Republic of Indonesia (RI) into the Islamic State of Indonesia (NII) with its chairman Daud Beureueh. On February 15, 1958, conflict between Aceh and RI was manifested in the emergence of the Revolutionary Government of the Republic of Indonesia (PRRI) and Permesta. During the New Order period, Aceh was agitated by social economic jealousy because of the inequity of labor issues between Javanese immigrants and local Acehnese. This prompted the birth of the Aceh Sumatra National Liberation Front (ASNLF), the separatist movement which later turned into the Independent Aceh Movement (GAM). In its development GAM turned into a strong organization under the leadership of Hasan Tiro and gained popular sympathy, including the attention of the international community.

Aceh tribe who live in the west coast, the Javanese who live in the plantation (inland) and Gayo and Alas tribe that many inhabit the mountains. In addition, there are Singkil, Simeuleu, Batak and Minangkabau. Nevertheless, referring to data in 2000, about $97.03 \%$ of Aceh's population is Muslim.

Heterogeneity can also be found in Langsa, the second-level (city) district with a population of about 148,945 people (BPS, 2010) with the majority of Aceh, Java, Malay, Gayo Padang, Batak and Chinese. They are concentrated in groups according to the community. Regarding the political tendency of the integration crisis in Aceh, interviews results of 51 villages in Langsa City indicate that 15 villages are dominated by GAM supporters, 20 majority villages have anti-GAM groups (supporters of PETA and Pro NKRI). While the other 16 villages have a near-balanced population between the two as well as groups that tend to be neutral like Chinese descents. The demographic condition affected the position and composition of the conflict as conflict broke out between GAM and the central government (the government in the capital Jakarta, the representation of NKRI). The outbreak of Acehnese ethno-nationalism and the assumption of Javanese colonialism stigmatized Javanese as an extension of the government's hand or so-called cuak (spy). The same title is also given to Acehnese ethnic who support the central government (Aceh RI) which is meant to refer to the betrayal. Also, for anyone who becomes a civil servant, TNI or POLRI. Langsa, especially in the post-New Order era, became a slaughterhouse for the cuak. It is this phenomenon of violence that contributes significantly to the emergence of open resistance to GAM by anti-GAM or pro-government groups. Aceh became an open arena for violent conflict: The Military Operations Area (DOM). As one of the areas with very high conflict activity, Langsa is basically inhabited by a society characteristically not much different from the people of Aceh in general, the adherents of a peaceful Islamic law but tend to be psychologically temperamental. Socioeconomic conditions in Langsa indeed have problems that are not much different: economic disparity and social jealousy. So, it's obvious that potential for conflict becomes very high. Meanwhile, Javanese live only a few blocks in groups, in addition to ethnic or other background populations categorized by GAM as cuak. This diversity of affiliation makes Langsa not only accustomed to violent events but also a place of exchange of prisoners from both sides.

As well as what happened in Langsa, some of the causes that allegedly contribute to the hatred and dissatisfaction of the Acehnese people to the central government are due to: 
- Acehnese people considered that they were colonialized by the newcomers, especially Javanese people.

- Vengeance for violence and conflicts to overcoming DI/TII as well as GAM in New Order era.

Unfair Aceh natural resource management that mischievously disadvantaged native Acehnese people.

- Central government's commitment related to the prerogative of Aceh on three fundamentals (religion, education and customs) has not been completed.

(Jurnal Hukum Ultimatum, 2003).

The Independent Aceh Movement (GAM) began on 4 December 1976 when Muhammad Hasan Tiro declared Aceh's independence. After attempting to escape from the Unitary State of the Republic of Indonesia with various violent attempts in 1983, GAM forces were defeated by the Indonesian military and Tiro fled abroad and later became a Swedish citizen. Tiro's departure from Indonesia does not mean that GAM is weakening. There was a series of violence acts therefore in 1992 the government controlled the situation completely after taking security measures which in turn had a negative impact on the implications of human rights abuses in large numbers. Commander of the armed forces, General Wiranto later apologized publicly for military excesses since1989 to 1998 on behalf of the government. However, the annulment of Military Operations Region status has no direct effect on the security stability in Aceh. GAM quickly re-seized the military demoralization until the armed confrontation began again.

Multidimensional crisis in Indonesia since mid-1997 causes Indonesia's security instability triggered worse the conflict in Aceh. This movement was getting worse because it got bigger and harder to extinguish. The end of the New Order era brought a fresh hope for reconciliation in Aceh, as the Reformation government revoked Aceh's status as a DOM. President B.J. Habibie even apologized to the people of Aceh for policy mistakes made by his predecessor. However, Habibie's brief leadership also has an effect on the peace climate that the situation has begun to calm down. There is a change of national political discourse that impact on the reconciliation process. Various parties have made various efforts to overcome violence. However, the chaos that remains still indicates a lack of comprehensive understanding about the root of the problem regarding the socio-cultural, economic, and political and security situation in Aceh.

Formally, the conflict between the Indonesian government and GAM ended with the signing of Helsinki memorandum of understanding on 15 August 2005. The Government of the Republic of Indonesia and GAM affirmed their commitment to resolve the Aceh conflict peacefully, thoroughly, sustainably and with dignity. The Helsinki MOU encompasses a number of issues including the Aceh government, the economic and social reintegration of former GAM members, and the reorganization of the TNI / POLRI role in Aceh. However, after the Helsinki MOU, the phenomenon of conflict and GAM's commitment to no longer want to escape from NKRI is still a debate among legislative, executive, and public elite. While the Acehnese themselves are still in a fragile state of conflict. Security in Aceh during the DOM and post-DOM period and post Helsinki MOU was equally problematic despite the intensity of different acts of violence. This can be seen from the data of the Aceh Regional Police regarding the number of crimes committed before the MOU and after the Helsinki MOU. Table 1. Comparison between Criminal Cases Situation before and after the MOU

\begin{tabular}{|c|c|c|c|}
\hline No & Cases & $\begin{array}{c}\text { Before MOU } \\
(15-10-2003 \text { to } \\
14-08-2005)\end{array}$ & $\begin{array}{c}\text { After MOU } \\
(15-10-2005 \mathrm{~s} / \mathrm{d} \\
14-08-2007)\end{array}$ \\
\hline 1 & Armed robbery & 10 & 172 \\
\hline 2 & Theft with violence & 29 & 126 \\
\hline 3 & Gequalificeerde deifstal & 4 & 125 \\
\hline 4 & Vehicle theft & 15 & 519 \\
\hline 5 & Threat/Blackmail & 37 & 52 \\
\hline 6 & Assault & 23 & 182 \\
\hline 7 & Defacement & 9 & 29 \\
\hline 8 & Nanggroe Tax & 25 & 32 \\
\hline 9 & Robbery & 2 & 9 \\
\hline 10 & Sweeping/GAM & 20 & 8 \\
\hline 11 & Vehicle Burning & 8 & 5 \\
\hline 12 & Drugs & 104 & 316 \\
\hline 13 & Burning & 51 & 184 \\
\hline 14 & Demonstrations & 15 & 76 \\
\hline \multicolumn{2}{|r|}{ Total } & 352 & 1833 \\
\hline
\end{tabular}

Source: Regional Police of Aceh 
Violence is a vicious cycle. Violence will bear violence, forming a society full of violent culture and that what has not been found in Aceh is the breaking of this culture of violence. Vehement conflicts and conflict areas in Aceh became much widened from the vertical conflict followed by horizontal conflicts. In fact, not a few civilians who actually become perpetrators of violence emerged in the form of armed civilian groups (Koran Tempo, 2003). The characteristics of the community in Aceh following the Helsinki MOU need to be considered as this may affect the dichotomy of the community in a way that can be explained when looking at the characteristics of the people in Aceh. Especially in Langsa, a heterogeneous region, but fragmented residential model makes the tendency of counter-productive thinking and counter-conflicting actions common. One ethnic or group attack by another ethnic or group contributes to the emergence of anti-GAM groups, and in its progression, it becomes supporters of the central government. For example, the Aceh Community Front formed by former Langsa mayor. There are other groups such as the GAM Separatist Front (FPSG), the Red-and-White Rescue Front (FPMP) and other strongholds in ethnic rivalries such as the Javanese Communities Communication Forum (FLWJ). In the end, the Langsa nationalist conception in general tends to follow the interests of conflict parties, as GAM supporters are those who Aceh-born and supporters of NKRI positioning themselves as the people of Indonesia. These excessive primordial attitudes and behaviors contribute to the vulnerability of social conflict. So, it can be said that peace in Langsa after Helsinki MOU is still in the order of peace creation (peacemaking) considering there are still quite a lot of violence happened.

Various approaches have been taken by the government to address the conflict in Aceh. Although armed force still played a great role dialogue and mediation are also implemented. In addition to President B.J. Habibie, President Abdurrahman Wahid has also sought reconciliation by initiating a dialogue mediated by the nongovernment organization Henry Dunant Center. The mediation resulted in the signing of a Joint Understanding on Humanitarian Pause for Aceh (JoU) with a focus on humanitarian assistance by Indonesian representatives, Ambassador Hasan Wirajuda and representatives of GAM Zaini Abdullah in Geneva on May 12, 2000 (HDC Center, 2003). However, often the dialogue is not implemented at the grassroots level in the field. A more effective peace agreement took place on August 15, 2005 during the reign of President Susilo Bambang Yudhoyono, with the signing of the Helsinki

MOU facilitated by the Swedish government. Under the Helsinki MOU, the government tried to reintegrate GAM into the community and provide economic aid and opportunities in local elections/local party formation (Bhakti: 2008, 21).

\section{After the Helsinki MOU: Between Peace and Conflict}

Although the MOU has been agreed upon by both parties, it appears that distrust and prejudice still linger mainly in both pro-GAM Acehnese community and anti-GAM Acehnese community. This has an effect on the ongoing dynamics of the conflict. According to the researchers, there are several things that can be considered as indicators of sustainability of the conflict. First, the ethnic sentiment and the depth of the conflict, the second is the difference of society's perception of peace, the next is the change of conflict structure and potential latent conflict, and the existence of symbolic rebellion is the fourth indicator.

Ethnic sentiments tend to be stronger in Langsa, a dichotomized multi-ethnic area. Sentiments between Aceh and Java contribute significantly to the emergence of Acehnese groups. It also affects the depths of the conflicts due to unequal social relations and the existence of unfair political allegiances. GAM provides government stereotypes as culturally invasive (the hegemony of Javanese cultural values resulting from transmigration programs), economically (the exploitation of Aceh's natural resources for "Java"), and politically (Java's dominance in bureaucracy and military) neocolonialism (Asnawi, 2002: 32). Following the MOU, peace in Aceh is still dominated by control and violence, or in other words a negative peace8. In this situation the estrangement and reluctance of communication between opposing groups is still very striking.

The resolution of Aceh conflict in the New Order era that is still violent-oriented government results in a prolonged conflict rather than reconciliation. It causes violence committed leads to new violence, making conflicting actor widened. Analytically, the developing conflict actors can be seen from three sides. The first is counter-separatist movement against the central government and pursuing for independence. The following is the central government with the reason to maintain the sovereignty of the Unitary Republic of Indonesia. Last but not least, anti-separatist movement supporting the central government to join the sovereignty of NKRI. Viewed from the community side, another name for two contradictory camps, they are Aceh GAM and Aceh RI. 
Conflict developments tend to shift from vertical conflicts to horizontal conflicts due to the development of structures and conflict actors. Negative peace is a state that demands a series of social structures providing security and protection from direct physical violence actions perpetrated by individuals, groups, or other combatants (Banualan, 2006).

In addition, there is a potential for latent conflict in Aceh and Langsa especially after the Helsinki MOU. Sudden changes of the phenomenon of conflict to the fragrance of peace, seems to point toward a critical point rather than a stable and measurable development. People are still experiencing dramatic conditions, or in other words people are still very careful in the interaction. On the other hand, Aceh's political privilege to form a local party also contains conflict. The Local Party is generally supported by the Aceh Transitional Committee (KPA) and the National Party is generally supported by the Defenders of the Homeland (PETA) which is the front of GAM's separatist resistance. One thing that is not covered by the Helsinki MOU is the dissolution of GAM. It appears that of the struggle to break away from the Unitary Republic of Indonesia is potential. Structurally, although the entity in GAM has merged into the Aceh Transitional Committee (KPA), its commanding nature has not yet fully disappeared. It became clear that GAM's existence was legally unenforceable, as did Wali Naggroe, Hasan Tiro. Thus it is conceivable that the true symbol of rebellion never fades.

\section{Conflict Resolution and Transformation}

Resolution is essentially a nonviolent conflict settlement process and puts forward democratic means. Dialogue and consensus become an important point for conflict resolution to reach a peace agreement for the common good with the hope of a zero-sum solution. The development of Aceh conflict after the Helsinki MOU is in a fairly complex position, so it needs gradual approach. The root of the conflict needs to be comprehended in depth and uses the frame of locality to take next step. The bottom up approach needs to be considered so that those with the aspiration can positively contribute to their own peace.

The wisdom and sincerity of reaccepting former GAM combatants is a key to peace in Aceh from the root structure. The actualization of such revenues may involve the Acehnese figures in the structure of the nation and state as a unifying symbol. This means that the integration of former GAM combatants into the community is not only state task (government) but also needs to be restored to the Acehnese tradition. The problem of reconciliation should be to involve all actors who have been involved in the conflict and all components of the community concerned with sustainable peace in Aceh. The signing of the Helsinki MOU can be regarded as the first step of reconciliation between GAM and RI. The next question is how it would be between GAM and non-GAM. It is therefore necessary to have a conflict resolution between GAM and Non-GAM represented by KPA, PETA and FORKAB. Reconciliation concerning all areas of life in order to open communications, change exclusiveness, and melt the dichotomy of Aceh RI with Aceh GAM. In addition, a positive role of the community is needed to avoid suspicion of hidden agendas beyond the peace commitment. The elimination of group domination is required in the new Aceh development process within the framework of the Unitary Republic of Indonesia (NKRI).

Conflict transformation also needs to be done to build a culture of peace and to increase institutional capacity both formal and non-formal. After reconciliation, the transformation of conflict is necessarily established in all aspects of social life. Conflict in the past is expected to be intervened in context, actors, structures, issues, groups, personnel, so that it can be transformed into an element of peace building. This is based on the reason that people who have different identities and interests in their own essence can work together if they are equally aware that peace is a shared need. In Langsa and other areas of Aceh, public spaces need to be opened to accommodate various social activities. Regardless of their identities, people can use it. In addition, approaches to individual groups and invitations to community leaders to aggravate peace require to be undertaken to forge a culture of cooperation and create a climate of openness, achieving a culture of sustainable peace.

Institutionally government development should be carried out in a participatory manner for all community groups. The three forms of conflict resolution, mediation, reconciliation, transformation is described in the following table. 
Table 2. Conflict Resolution between Aceh GAM and Aceh RI

\begin{tabular}{|c|c|c|c|}
\hline $\mathrm{NO}$ & CONFLICT RESOLUTION & LANGSA & $\mathrm{ACEH}$ \\
\hline 1 & Mediation & $\begin{array}{l}\text { - Rector Forum } \\
\text { - City government } \\
\text { - Aceh region government }\end{array}$ & $\begin{array}{l}\text { - Aceh region government } \\
\text { - Central government }\end{array}$ \\
\hline 2 & Reconciliation & $\begin{array}{l}\text { 1. Elite reconciliation } \\
\text { - Executives (regent / } \\
\text { mayor) } \\
\text { - Chief / KPA and PETA } \\
\text { figures } \\
\text { 2. Mass reconciliation } \\
\text { - Regional approach } \\
\text { - Involving formal/non } \\
\text { formal figures }\end{array}$ & $\begin{array}{l}\text { Elite reconciliation primarily } \\
\text { involves KPA, PETA and } \\
\text { FORKAB followed by each figures } \\
\text { as well as ALA and ABAS } \\
\text { supporters in the regional } \\
\text { government election. }\end{array}$ \\
\hline 3 & Transformation & \multicolumn{2}{|c|}{$\begin{array}{l}\text { 1. } \begin{array}{l}\text { Context: national conflict -> Local (Langsa) -> Intergroup } \\
\text { (Aceh GAM with Aceh RI) }\end{array} \\
\text { 2. Structure: Interventions of parties trusted by conflicting } \\
\text { groups to build trust and reduce dominance } \\
\text { 3. Actors: Change of leadership of the parties, trying to } \\
\text { understand each other and encourage the involvement of } \\
\text { women } \\
\text { 4. Problems: Changing the issue of free fundamental into self- } \\
\text { government implemented in the mechanism of democracy } \\
\text { 5. Group and personal: The awareness and attitude of accepting } \\
\text { the previously opposing party for the sake of broader } \\
\text { community interest. }\end{array}$} \\
\hline
\end{tabular}

\section{Conclusion}

The Peace Solution through the Helsinki MOU has indeed significantly reduced the exacerbation of the conflict. Nevertheless, the analysis result of existing suggests that the solution have not been able to resolve the conflict for realizing positive peace. For example, it is shown by the facts that there is still a conflict between Aceh GAM and Aceh RI. Deeper consideration, the sustainability of conflicts after MOU is due to the persistence of ethnic sentiments, differences in perceptions of peace, changes in conflict structures and potential conflicts, as well as symbolic insurrections. The widespread expansion of conflict actors is one of the important points to create peace. In the problem of the Helsinki MOU, applying the theory of Hugh Miall, it suggests that non-GAM or Acehnese society is not properly accommodated in the agreement. This theory is relevant when it is viewed as an urgency of new life development involving all parties of society through reconciliation and conflict transformation. However, decision-making in accordance with the context of conflict requires an actual realization. The source of the conflict in Aceh, including Langsa, is no longer a matter of domination, inequality, and economic exploitation, but rather ideology. It suggests that conflict resolution should also be dynamic as the nature of conflict resolution in general.

In accordance, these are several recommended considerations:

- Stages of conflict resolution must be processed through dialogue and mediation to achieve reconciliation and conflict transformation.

- The central government and local government must be a neutral entity and properly positioned so that a strong country can be created. In this case government assertiveness is necessary, especially in the case of politics (state sovereignty) and economy to prioritize the importance of equitable development.

- Establishing communication forums by all communities and institutions. In the hope of forming a mental concept of a peaceful society.

- Opening the industry for the welfare of the people through the contributing opportunity to build the region based on their specifications. 
- Business actors are expected to help transforming the mindset of people, especially academics to be able to increase entrepreneurial skill and reduce unemployment.

- Enforcing law and improving law enforcement agencies performance to create conducive environment.

- It is necessary to establish a commission or conflict analysis agency of Aceh, even if it is needed, a national level commission should be considered. The issue of conflict resolution in Aceh that is not immediately reconciled after the signing of the MOU provides a meaningful lesson that peace is a long and sustainable process.

\section{Bibliography}

Asnawi, Sahlan. (2002). Motivation Theory (Approach of Psychology, Industry, Organization). Jakarta: Studi Press.

Badan Pusat Statistik (Statistics Indonesia). (2010). Demographic Census: Aceh Province. [online] BPS Website:http://sp2010.bps.go.id/index.php/site?id=11\& wilayah=Aceh, Accessed on 20 Juli 2018.

Bhankti, Ikrar Nusa (2008). Peace Veranda, Aceh Three Years After The Helsinki MoU. Jakarta: Pustaka Pelajar. Cresswell, John W. (2003). Research Design, Qualitative, and Quantitative Approach. Sage Publication.

Galtung, Johan. (1996). Peace Studies. "Peace or Conflict, Development and Conflict, Development and Civilization”. Surabaya: Pustaka Pelajar.

Ijie, Reagen Origenes (2003). Papua People Congress II, Basic Resolution Towards Free Papua. Jakarta: PT. Bumi Intitama Sejahtera.

Julan, Ting. (2005). Conflict Settlement in Aceh. Aceh in the process of Reconstruction and Reconciliation. Jakarta: LIPI Pers.

Koran Tempo. (2003). May \& January.

Lawang, Robert MZ. (1986). Modern Class Sociology Theory.

Jakarta: Gramedia.

Miall, Hugh. (2002). Contemporer Conflict Resolution. End, Prevent, Manage, And Transform Politic, Social, Religion, and Racial-Based Conflict. Jakarta: Raja Grafindo Persada.

Jurnal Hukum Ultimatum (Ultimatum Law Journal). (2003). August Edition. 